\title{
Reassessment of the Phylogenetic Position of the Bacterium Associated with Whipple's Disease and Determination of the 16S-23S Ribosomal Intergenic Spacer Sequence
}

\author{
MATTHIAS MAIWALD, ${ }^{1 *}$ HANS-JÜRGEN DITTON,${ }^{1}$ AXEL VON HERBAY, ${ }^{2}$ \\ FREDERICK A. RAINEY, ${ }^{3}$ AND ERKO STACKEBRANDT ${ }^{3}$ \\ Hygiene-Institut der Universität, Abteilung Hygiene und Medizinische Mikrobiologie, ${ }^{1}$ and \\ Pathologisches Institut der Universität, ${ }^{2} 69120$ Heidelberg, and Deutsche Sammlung \\ von Mikroorganismen und Zellkulturen GmbH, 38124 Braunschweig, ${ }^{3}$ Germany
}

\begin{abstract}
Whipple's disease is a rare chronic illness associated with an unculturable bacterium that is constantly present in affected tissues. This bacterium was previously characterized at the molecular level by PCR and sequencing of the 16S rRNA gene. On the basis of 1,321 nucleotides of the sequence of its gene coding for $16 \mathrm{~S}$ rRNA (16S rDNA), a phylogenetic relationship to the actinomycetes was established. In this study, we determined an almost complete $16 \mathrm{~S}$ rDNA sequence (1,495 nucleotides), the $16 \mathrm{~S}-23 \mathrm{~S}$ ribosomal intergenic spacer sequence, and 200 nucleotides of the $23 \mathrm{~S}$ rRNA gene. The $16 \mathrm{~S}$ rDNA sequence was compared with the large number of actinomycete sequences that have been added to the database since the original study. Phylogenetic analysis revealed a branching position as the deepest branch of the cluster comprising the actinomycetes with group B peptidoglycan between this group and the family Cellulomonadaceae. This provides additional information on the phylogenetic position of this bacterium and some clues as to its characteristics. The spacer region between the $16 \mathrm{~S}$ and $23 \mathrm{~S}$ rRNA genes is 294 nucleotides long and does not contain tRNA genes. As has been shown in other instances, the increased variability of the ribosomal intergenic spacer compared with the 16S rRNA gene makes it a potential target for use in the differentiation of strains of the bacterium associated with Whipple's disease.
\end{abstract}

Whipple's disease is a rare chronic illness with intestinal and extraintestinal manifestations. A constant feature of the disease is the appearance of periodic acid-Schiff stain-positive cellular inclusions detected by histology. These periodic acidSchiff stain-positive inclusions contain bacteria visible by electron microscopy that are approximately $0.2 \mu \mathrm{m}$ wide by 1.5 to $2.5 \mu \mathrm{m}$ long and have a typical trilaminar appearance of the cell wall (4). Numerous attempts to culture these bacteria on artificial media or in cell culture have failed or have yielded contaminants (3). The bacterium associated with Whipple's disease (Whipple's disease bacterium) was characterized at the molecular level by PCR and universal bacterial primers for the 16S rRNA gene; the resulting PCR products were sequenced $(36,48)$. In a first investigation, less than $50 \%$ (645 nucleotide positions) of the bacterial 16S rRNA gene was sequenced and a relationship to the actinomycetes was established, with the closest relative reported to be Rhodococcus equi (48). Later, approximately $85 \%$ of the $16 \mathrm{~S}$ rRNA gene was sequenced (36). Analysis of this sequence comprising 1,321 bp confirmed a phylogenetic relationship to the actinomycetes (36). The closest phylogenetic relatives within the order Actinomycetales were members of a group designated the "actinobacteria" comprising representatives of the genera Actinomyces, Rothia, Arthrobacter, Micrococcus, Terrabacter, and Dermatophilus for which sequence data had been previously determined and made available via the public databases and the Ribosomal Database Project $(25,36)$. On the basis of the novelty of the

\footnotetext{
${ }^{*}$ Corresponding author. Mailing address: Hygiene-Institut der Universität Heidelberg, Im Neuenheimer Feld 324, 69120 Heidelberg, Germany. Phone: 49-6221-567815. Fax: 49-6221-564343. Electronic mail address: un69mm@genius.embnet.dkfz-heidelberg.de.
}

sequence of the gene coding for 16S rRNA (16S rDNA) of the Whipple's disease bacterium and its lack of close relationship to any actinomycete for which $16 \mathrm{~S}$ rDNA sequence data were available, the name "Tropheryma whippelii" was proposed (36). The determination of the almost complete 16S rDNA sequence allowed the design of two taxon-specific PCR primers, the use of which led to the detection of almost identical sequences in tissue from five patients with Whipple's disease (36). Subsequently, a diagnostic PCR system which detected the specific DNA fragment in tissue from 30 additional patients with the disease was designed (45).

The genes coding for rRNA molecules are organized in operons and arranged in the order $5^{\prime}-16 \mathrm{~S}-23 \mathrm{~S}-5 \mathrm{~S}-3^{\prime}$, in which the individual rRNA genes are separated by spacer regions (39). The size and sequence composition of the spacer region between the 16S rRNA and 23S rRNA genes have been investigated in a number of bacterial taxa, and its potential use in diagnostics and identification has been highlighted (11) because of the greater sequence variability of the spacer, compared with that of the $16 \mathrm{~S}$ rRNA gene, among bacterial strains or species.

In this present study, we determined an almost complete $16 \mathrm{~S}$ rDNA sequence comprising 1,495 nucleotides for a Whipple's disease bacterium. This new sequence was compared with the considerable number of actinomycete $16 \mathrm{~S}$ rRNA sequences that have been added to the database $(1,16-19,21,29-37,40$, $43,46,47)$ since the characterization of the Whipple's disease bacterium by Relman et al. (36). The phylogenetic analysis provides additional information on the phylogenetic position of this bacterium and allows some speculation as to the type of organism. The spacer region between the $16 \mathrm{~S}$ rRNA and $23 \mathrm{~S}$ rRNA genes was amplified with a primer specific for the Whip- 
ple's disease bacterium and a universal bacterial primer binding in the $23 \mathrm{~S}$ rDNA, and the sequence was determined.

\section{MATERIALS AND METHODS}

Preparation of DNA from biopsy material. DNA from the Whipple's disease bacterium was extracted from the duodenal biopsy of a patient whose case was previously reported (27). Prior to PCR, the biopsy was deparaffinized by shaking it twice in $1 \mathrm{ml}$ of $n$-hexane and twice in $500 \mu \mathrm{l}$ of ethanol, each step lasting for $30 \mathrm{~min}$. The sample was centrifuged for $5 \mathrm{~min}$ at $18,000 \times \mathrm{g}$ between each of these steps. The biopsy was then dried under vacuum, subsequently digested for $2 \mathrm{~h}$ at $56^{\circ} \mathrm{C}$ in $40 \mu \mathrm{l}$ of lysis buffer $(50 \mathrm{mM} \mathrm{KCl}, 10 \mathrm{mM}$ Tris, $1.5 \mathrm{mM} \mathrm{MgCl}, 1 \%$ Triton $\mathrm{X}-100,200 \mu \mathrm{g}$ of proteinase $\mathrm{K}$ per $\mathrm{ml}$ ), and boiled for $10 \mathrm{~min}$ after the addition of $20 \mu \mathrm{l}$ of a $20 \%$ Chelcx suspension (biotechnology-grade chelating resin Chelex 100; Bio-Rad Laboratories, Richmond, Calif.). Ten microliters of the supernatant was added to the PCR.

PCR amplification. The composition of the PCR mix was the same as described previously (26), and the cycling profile consisted of initial denaturation at $95^{\circ} \mathrm{C}$ for $3 \mathrm{~min}$ followed by 40 cycles of denaturation at $95^{\circ} \mathrm{C}$ for $45 \mathrm{~s}$, annealing at $58^{\circ} \mathrm{C}$ for $1 \mathrm{~min}$, extension at $72^{\circ} \mathrm{C}$ for $1 \mathrm{~min}$, and final extension at $72^{\circ} \mathrm{C}$ for 2 min. To amplify a 1,249-bp fragment from the 16S rRNA gene, the universal bacterial primer p8FPL (5'-AGTTTGATCCTGGCTCAG) and the Whipple's disease bacterium-specific primer pW2RB (5'-ATTCGCTCCACCTTGCGA) of Relman et al. (36) were used in a modified version, both without restriction enzyme recognition sites. To obtain the $3^{\prime}$ end of the $16 \mathrm{~S}$ rRNA gene, the $5^{\prime}$ end of the 23S rRNA gene and the intergenic spacer, the Whipple's disease bacterium-specific primer pW3FE (5'-AGAGATACGCCCCCCGCAA, without restriction sites) of Relman et al. (36), and the universal primer 2 for the 23S rRNA gene (5'-GGTACCTTAGATGTTTCAGTTC) of Kostman et al. (20) were used. PCR products were checked on $5 \%$ polyacrylamide gels with previously described electrophoresis conditions (26), subsequently transferred to nylon membranes, and hybridized at $60^{\circ} \mathrm{C}$ with the ${ }^{32} \mathrm{P}$-labeled oligonucleotide "whip3" (5'-TGGTACAGAGGGTTGCAATA), which is located on the 16S rRNA of the Whipple's disease bacterium between the primers pW3FE and pW2RB of Relman et al. (36). To obtain pure DNA for sequencing, electrophoresis was performed on $1 \%$ agarose gels. DNA fragments were cut out from the agarose gels and purified with the Jetsorb gel extraction kit (Genomed, Research Triangle Park, N.C.). Sequencing was performed with the AmpliCycle Sequencing Kit (Perkin-Elmer, Norwalk, Conn.) with incorporation of $\left[\alpha-{ }^{33} \mathrm{P}\right] \mathrm{dATP}$. The reaction products were electrophoresed on $6 \%$ standard sequencing gels at constant power of $50 \mathrm{~mA}$ and then exposed to X-ray films. To confirm the results of manual sequencing, the reactions were repeated with the Taq DyeDeoxy Terminator sequencing kit (Applied Biosystems, Foster City, Calif.) according to the manufacturer's protocol. The sequence reactions were then electrophoresed with the Applied Biosystems 373A DNA sequencer. Sequences were manually aligned with published sequences from members of the actinomycete line of descent.

Phylogenetic analyses. The data set used for the phylogenetic analyses comprised 1,304 unambiguous nucleotides between positions 41 and 1449 (Escherichia coli numbering of positions). Phylogenetic analyses were carried out with the range of programs provided by the ARB ("a software environment for sequence data") (42), the PHYLIP package (7), and the Ribosomal Database Project (25). Phylogenetic trees were generated by the maximum-likelihood, neighbor-joining, least squares, and maximum-parsimony algorithms. The tree topologies were evaluated by bootstrap analyses with 1,000 resamplings of the sequence data with SEQBOOT (6).

Nucleotide sequence accession numbers. The accession numbers of the sequences of the reference strains (strain designations given when available) used in the phylogenetic analyses are as follows: Actinoplanes philippinensis DSM $43019^{\mathrm{T}}(\mathrm{X} 93187)$, Agrococcus jenensis DSM 9580 ${ }^{\mathrm{T}}$ (X92492), Agromyces ramosus DSM $43045^{\mathrm{T}}$ (X77447), Arthrobacter globiformis DSM 20124 ${ }^{\mathrm{T}}$ (M23411), Atopobium minutum ATCC $33267^{\mathrm{T}}$ (M59059), Aureobacterium liquefaciens DSM $20638^{\mathrm{T}}$ (X77444), "Brevibacterium helvolum" DSM 20419 (X77440), Brevibacterium linens DSM 20425 ${ }^{\mathrm{T}}$ (X77452), Cellulomonas biazotea DSM 20112 ${ }^{\mathrm{T}}$ (X83802), Cellulomonas cellasea DSM 20118 ${ }^{\mathrm{T}}$ (X83804), Cellulomonas cellulans DSM $43879^{\mathrm{T}}$ (X83809), Cellulomonas fermentans DSM $3133^{\mathrm{T}}$ (X83805), Cellulomonas flavigena DSM $20109^{\mathrm{T}}$ (X83799), Cellulomonas gelida DSM $20111^{\mathrm{T}}$ (X83800), Cellulomonas hominis CE40 (X82598), Clavibacter michiganense subsp. michiganense DSM $46364^{\mathrm{T}}$ (X77435), Clavibacter xyli subsp. cynodontis (M60935), "Connebacterium aquaticum" DSM 20146 (X77450), Curtobacterium citreum DSM 20528 ${ }^{\mathrm{T}}$ (X77436), Dermacoccus nishinomiyaensis DSM 20448 (X87757), Jonesia denitrificans DSM 20603 ${ }^{\mathrm{T}}$ (X83811), Kocuria rosea DSM $20447^{\mathrm{T}}$ (X87756), Lentzea albidocapillata DSM $44073^{\mathrm{T}}$ (X84321), Microbacterium lacticum DSM $20427^{\mathrm{T}}$ (X77441), Micrococcus luteus (M38242), Nesterenkonia halobia DSM 20541 ${ }^{\mathrm{T}}(\mathrm{X} 80747)$, Nocardia asteroides DSM $43757^{\mathrm{T}}(\mathrm{X} 80606)$, Promicromonospora enterophila DSM 43852 ${ }^{\mathrm{T}}$ (X83807), Rathayibacter rathayi DSM $7485^{\mathrm{T}}$ (X77439), Rothia dentocariosa ATCC 17931 ${ }^{\mathrm{T}}$ (M59055), Sporichthya polymorpha DSM 46113' (X72377), Streptomyces griseus (M76388), and Streptosporangium roseum DSM 43021 ${ }^{\mathrm{T}}$ (X89947). The sequence determined for the Whipple's disease bacterium in this study and the structural features associated with it have been deposited in the EMBL database under accession no. X99636.

\section{RESULTS AND DISCUSSION}

By using the combination of primers described above, two PCR products were obtained; both were slightly larger than 1 $\mathrm{kbp}$ on polyacrylamide gels and both hybridized with the oligonucleotide whip3. The sequences of both PCR products contained an identical overlapping fragment of 230 bases which is located between the Whipple's disease bacteriumspecific primers pW3FE and pW2RB of Relman et al. (36). The whole sequence is 1,989 nucleotides long and ranges from position 28 in the 16S rRNA to position 188 in the 23S rRNA of the corresponding genes of E. coli (accession no. J01695). The sequence contains 1,495 nucleotides of the 16S rRNA gene and 200 nucleotides of the 23S rRNA gene of the Whipple's disease bacterium. The first 1,321 nucleotides are identical to the sequence of the Whipple's disease bacterium that was reported earlier by Relman et al. (36).

All methods of phylogenetic analysis used in this study gave identical branching patterns with respect to the phylogenetic position of the Whipple's disease bacterium. Differences in the positions and relationships of the deep branching organisms were observed between the different analyses. In all phylogenetic analyses, the branching position of the Whipple's disease bacterium was as the deepest branch of the cluster composed of the actinomycetes with group B peptidoglycan, between this group and the members of the family Cellulomonadaceae. A phylogenetic tree was calculated with the 16S rRNA sequences of representatives of the major phylogenetic groups within the order Actinomycetales (Fig. 1). Pairwise evolutionary distances were computed with the correction of Jukes and Cantor (13). The phylogenetic dendrogram shown in Fig. 1 was reconstructed from the distance matrices by the neighbor-joining method (38). Although the position of the Whipple's disease bacterium between the actinomycetes with group B peptidoglycan and the cellulomonads was recovered in all phylogenetic analyses, the bootstrap analyses do not indicate a very high level of confidence at $83 \%$ associated with this position. The bootstrap values indicated in Fig. 1 show that the cellulomonad group was also recovered in $83 \%$ of the resamplings while the cluster of actinomycetes with group B peptidoglycan was recovered in only $81 \%$ of the analyses. When the 16S rDNA sequence similarities of the Whipple's disease bacterium, the representatives of the actinomycetes with group B peptidoglycan, and the cellulomonads shown in Fig. 1 were calculated, the 16S rDNA similarities of the Whipple's disease bacterium and the actinomycetes with group B peptidoglycan are in the range of 90.0 to $91.6 \%$ compared with a range of 89.9 to $91.6 \%$ for the cellulomonads. The highest similarities are found to the two species "Corynebacterium aquaticum" and Cellulomonas cellasea, both at $91.6 \%$. The peptidoglycan types of the organisms within the clusters comprising the phylogenetic neighbors of the Whipple's disease bacterium are very different in structure. On one hand, there is the rare group B peptidoglycan which is possessed by all members of one of the neighboring clusters, while the other cluster, the cellulomonads, has group A peptidoglycan. Most of the group B peptidoglycan-containing actinomycetes are environmentally occurring or are plant pathogens (2) and have only rarely been encountered in clinical specimens (8). Members of the family Cellulomonadaceae have generally been isolated from soil, but strains of Oerskovia turbata (shown to be highly related to Promicromonospora enterophila [35]) have been isolated from clinical sources (41). Recently, Funke et al. (9) have described Cellulomonas hominis isolated from clinical samples.

The phylogenetic position determined in this study for the Whipple's disease bacterium based on comparison of almost 


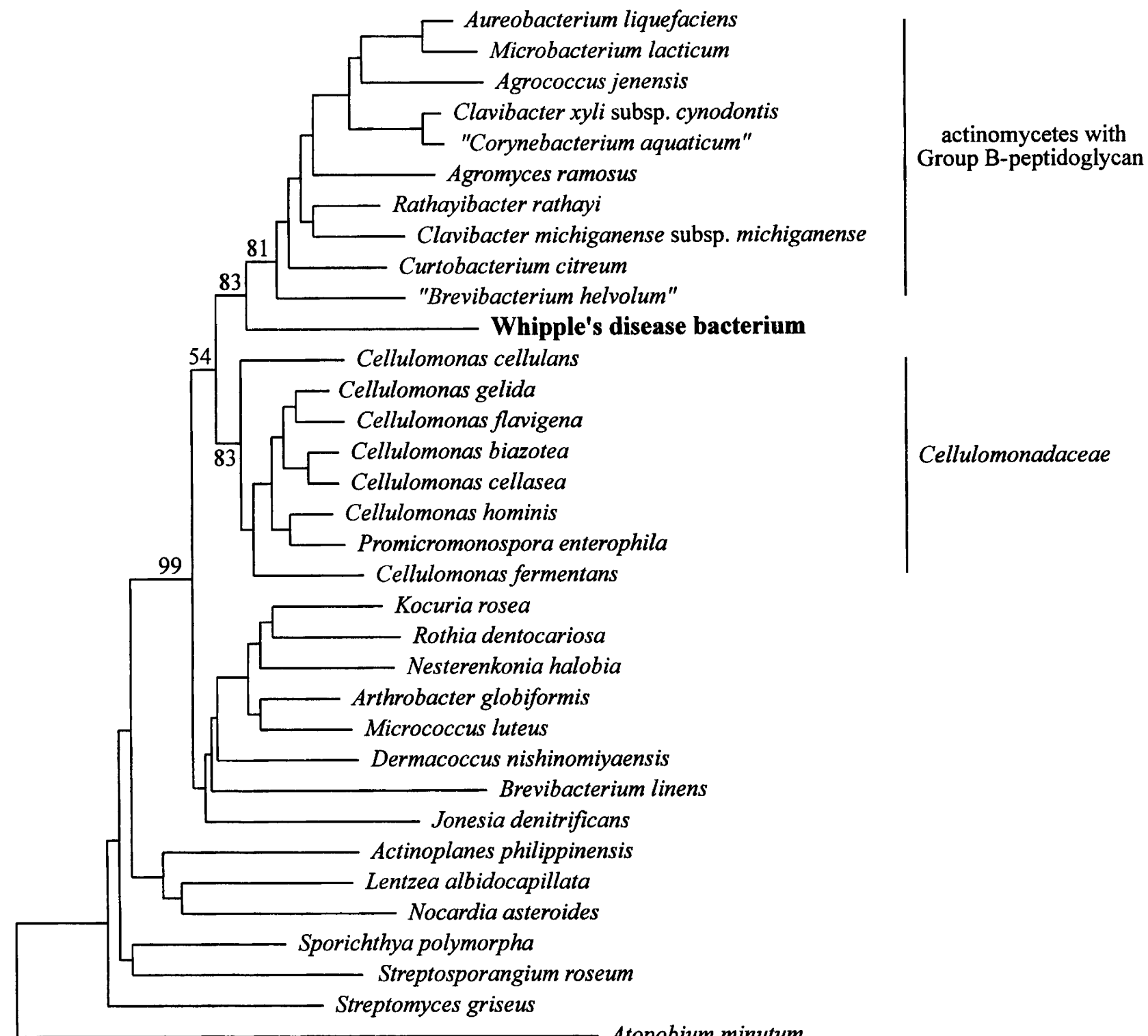

$5 \%$

FIG. 1. Phylogenetic dendrogram displaying the relationship of the Whipple's disease bacterium to other representatives of the actinomycetes. The scale bar represents five inferred nucleotide substitutions per 100 nucleotides. Numbers at branching points indicate bootstrap values.

complete $16 \mathrm{~S}$ rDNA sequences of more than 25 reference organisms from a group that Relman et al. (36) designated "actinobacteria" is different from the position previously shown (36). The Whipple's disease bacterium is not the deepest branching organism of the actinobacteria group but branches within this group. The phylogenetic analysis presented here allows us to eliminate the possibility that the Whipple's disease bacterium is highly related to any of the actinomycete taxa for which sequences have become available since the analysis of Relman (36) with the then-available limited database. The determination of the phylogenetic position of the Whipple's disease bacterium 16S rDNA sequence between the actinomycetes with group B peptidoglycan and the cellulomonads may provide some clues as to its characteristics. Future studies should now be aimed at the determination of the peptidogly- can type of the Whipple's disease bacterium in order to determine its affiliation to either neighboring taxon at the chemotaxonomic level. Such data would complement the phylogenetic data available and indicate the significance of the intermediate branching point of the Whipple's disease bacterium demonstrated in this study.

The spacer region between the 16S and 23S rRNA genes determined in this study is 294 nucleotides long and does not contain tRNA genes. Searches for sequence similarity to the spacers of other actinomycetes (Frankia spp., accession numbers M55343 and M88466; Streptomyces sp., M27245; Clavibacter spp., L43095 and U09379) revealed an overall low homology (approximately 40\%) to the respective genes of these species, indicating the lack of comparability of spacer regions between phylogenetically distinct taxa. A region of higher sim- 
ilarity can be found. The highest similarity of $87 \%$ is found in a 31-nucleotide-long stretch within the $3^{\prime}$ end of the spacer region of the Whipple's disease bacterium and Clavibacter michiganense. This stretch contains the conserved motifs of a putative box A (CGATATTTTGA) and box C (GTGGACGCG $A G$ ), as well as an interbox stretch (GAACTGCACA). The length of the intergenic spacer between the 16S rRNA and 23S rRNA genes of the Whipple's disease bacterium (294 bp) is within the size range reported for the majority of other grampositive bacteria with high $\mathrm{G}+\mathrm{C}$ content. For example, the spacers of mycobacteria have been found to vary in length between 276 and 362 bp $(12,14)$, those of Streptomyces species vary between 277 and $304 \mathrm{bp}$ (15), and a size of 411 bp has been determined for the Frankia sp. (28). A recent report of the spacer size for 29 strains of 18 Bifidobacterium species showed them to range in size from 274 to $552 \mathrm{bp}$ (21). The spacer regions of Clavibacter michiganense subspecies, organisms with group B peptidoglycan, have been determined to be approximately $500 \mathrm{bp}(22)$. The $16 \mathrm{~S}-23 \mathrm{~S}$ intergenic spacer of the Whipple's disease bacterium did not contain tRNA genes which are commonly found in the spacers of gram-negative bacteria (5) and of low- $\mathrm{G}+\mathrm{C}$ gram-positive bacteria $(24,44)$. This is also in concordance with the findings of Liesack et al. (23), who assumed that the absence of tRNA genes and an approximate length of 300 nucleotides are general features of $16 \mathrm{~S}-23 \mathrm{~S}$ intergenic spacers of actinomycetes.

The 16S-23S intergenic spacer is a potential target for species identification and strain differentiation, because it has greater variability than the $16 \mathrm{~S}$ rRNA gene. The spacer has been successfully used for strain differentiation in some bacterial species, such as Burkholderia (Pseudomonas) cepacia (20) or Staphylococcus aureus (10). The sequence of the spacer of the Whipple's disease bacterium should be determined for additional strains to check whether there are differences at the spacer level between strains from individual patients. The sequence data and the results of its analysis presented here provide additional information on the phylogenetic position of the Whipple's disease bacterium which can be used to further investigate the characteristics of this organism. The possibility of determining the $16 \mathrm{~S}$ to $23 \mathrm{~S}$ rRNA spacer region sequence has been demonstrated, and this should now be applied to a number of patients in order to investigate its use in strain differentiation.

\section{ACKNOWLEDGMENT}

Part of this work was supported by a grant from the Deutsche Forschungsgemeinschaft (Ma 1663/2-1).

\section{REFERENCES}

1. Chun, J., and M. Goodfellow. 1995. A phylogenetic analysis of the genus Nocardia with 16S rRNA gene sequences. Int. J. Syst. Bacteriol. 45:240-245.

2. Collins, M. D., and J. F. Bradbury. 1992. The genera Agromyces, Aureobacterium, Clavibacter, Curtobacterium, and Microbacterium, p. 1355-1368. In A. Balows, H. G. Trüper, M. Dworkin, W. Harder, and K.-H. Schleifer (ed.), The prokaryotes, 2nd ed. Springer-Verlag, New York.

3. Dobbins, W. O., III. 1987. Whipple's disease. Charles C Thomas, Publisher, Springfield, Ill.

4. Dobbins, W. O., III, and H. Kawanishi. 1981. Bacillary characteristics in Whipple's disease: an electron microscopic study. Gastroenterology 80: 1468-1475.

5. East, A. K., and M. D. Collins. 1993. Molecular characterization of DNA encoding 23S rRNA and 16S-23S rRNA intergenic spacer regions of Aeromonas hydrophila. FEMS Microbiol. Lett. 106:129-134.

6. Felsenstein, J. 1985. Confidence limits on phylogenies: an approach using the bootstrap. Evolution 39:783-791.

7. Felsenstein, J. 1993. PHYLIP (phylogenetic inference package) version 3.5.1. Department of Genetics, University of Washington, Seattle.

8. Funke, G., E. Falsen, and C. Barreau. 1995. Primary identification of $\mathrm{Mi}$ crobacterium spp. encountered in clinical specimens as CDC coryneform group A-4 and A-5 bacteria. J. Clin. Microbiol. 33:188-192.
9. Funke, G., C. P. Ramos, and M. D. Collins. 1995. Identification of some clinical strains of CDC coryneform group A-3 and A-4 bacteria as Cellulomonas species and proposal of Cellulomonas hominis sp. nov. for some group A-3 strains. J. Clin. Microbiol. 33:2091-2097.

10. Gürtler, V., and H. D. Barrie. 1995. Typing of Staphylococcus aureus by PCR-amplification of variable length 16S-23S rDNA spacer regions: characterization of spacer sequences. Microbiology 141:1255-1265.

11. Gürtler, V., and V. A. Stanisich. 1996. New approaches to typing and identification of bacteria using the 16S-23S rDNA spacer region. Microbiology 142:3-16.

12. Ji, Y., M. J. Colston, and R. A. Cox. 1994. The ribosomal RNA ( $r m$ ) operons of fast-growing mycobacteria: primary and secondary structures and their relation to $r m$ operons of pathogenic slow-growers. Microbiology 140:28292840.

13. Jukes, T. H., and C. R. Cantor. 1969. Evolution of protein molecules, p. 21-132. In H. N. Munro (ed.), Mammalian protein metabolism. Academic Press, New York.

14. Kempsell, K. E., Y.-E. Ji, I. C. E. Estrada-G., M. J. Colston, and R. A. Cox. 1992. The nucleotide sequence of the promoter, 16S rRNA and spacer region of the ribosomal RNA operon of Mycobacterium tuberculosis and comparison with Mycobacterium leprae precursor rRNA. J. Gen. Microbiol. 138:1717-1727.

15. Kim, E., H. Kim, S. P. Hong, K. H. Kang, Y. H. Kho, and Y. H. Park. 1993. Gene organization and primary structure of a ribosomal RNA gene cluster from Streptomyces griseus subsp. griseus. Gene 132:21-31.

16. Kim, S.-B., J.-H. Yoon, H. Kim, S. T. Lee, Y.-H. Park, and M. Goodfellow. 1995. A phylogenetic analysis of the genus Saccharomonospora conducted with 16S rRNA gene sequences. Int. J. Syst. Bacteriol. 45:351-356.

17. Koch, C., R. M. Kroppenstedt, and E. Stackebrandt. 1996. Intrageneric relationships of the actinomycete genus Micromonospora. Int. J. Syst. Bacteriol. 46:383-387.

18. Koch, C., F. A. Rainey, and E. Stackebrandt. 1994. 16S rDNA studies on members of Arthrobacter and Micrococcus: an aid to their future taxonomic restructuring. FEMS Microbiol. Lett. 123:167-172.

19. Korn-Wendisch, F., F. A. Rainey, R. M. Kroppenstedt, A. Majazza, and E. Stackebrandt. 1995. Thermocrispum gen. nov., a new genus of the order Actinomycetales, and description of Thermocrispum municipale sp. nov. and Thermocrispum agreste sp. nov. Int. J. Syst. Bacteriol. 45:67-77.

20. Kostman, J. R., T. D. Edlind, J. J. LiPuma, and T. L. Stull. 1992. Molecular epidemiology of Pseudomonas cepacia determined by polymerase chain reaction ribotyping. J. Clin. Microbiol. 30:2048-2087.

21. Leblond-Bourget, N., H. Philippe, I. Mangin, and B. Decaris. 1996. 16S rRNA and $16 \mathrm{~S}$ to $23 \mathrm{~S}$ internal transcribed spacer sequence analyses reveal inter- and intraspecific Bifidobacterium phylogeny. Int. J. Syst. Bacteriol. 46:102-111.

22. Li, X., and S. H. De Boer. 1995. Selection of polymerase chain reaction primers from an RNA intergenic spacer region for the specific detection of Clavibacter michiganensis subsp. sepedonicus. Phytopathology 85:837-842.

23. Liesack, W., S. Sela, H. Bercovier, C. Pitulle, and E. Stackebrandt. 1991. Complete nucleotide sequence of the Mycobacterium leprae 23S and $5 \mathrm{~S}$ rRNA genes plus flanking regions and their potential in designing diagnostic oligonucleotide probes. FEBS Lett. 281:114-118.

24. Loughney, K., E. Lund, and J. E. Dahlberg. 1982. tRNA genes are found between the 16S and 23S rRNA genes in Bacillus subtilis. Nucleic Acids Res. 10:1607-1624.

25. Maidak, B. L., N. Larsen, M. J. McCaughey, R. Overbeek, G. J. Olsen, K. Fogel, J. Blandy, and C. R. Woese. 1994. The Ribosomal Database Project. Nucleic Acids Res. 22:3485-3487.

26. Maiwald, M., H. J. Meier-Willersen, M. Hartmann, and A. von Herbay 1995. Detection of Tropheryma whippelii DNA in a patient with AIDS. J. Clin. Microbiol. 33:1354-1356.

27. Meier-Willersen, H. J., M. Maiwald, and A. von Herbay. 1993. Morbus Whipple in Assoziation mit opportunistischen Infektionen. Dtsch. Med. Wochenschr. 118:854-860.

28. Normand, P., B. Cournoyer, P. Simonet, and S. Nazaret. 1992. Analysis of a ribosomal RNA operon in the actinomycete Frankia. Gene 111:119-124.

29. Pascual, C., P. A. Lawson, J. A. E. Farrow, M. N. Gimenez, and M. D. Collins. 1995. Phylogenetic analysis of the genus Corynebacterium based on 16S rRNA gene sequences. Int. J. Syst. Bacteriol. 45:724-728.

30. Rainey, F. A., J. Burghardt, R. M. Kroppenstedt, S. Klatte, and E. Stackebrandt. 1995. Phylogenetic analysis of the genera Rhodococcus and Nocardia and evidence for the evolutionary origin of the genus Nocardia from within the radiation of Rhodococcus species. Microbiology 141:523-528.

31. Rainey, F. A., P. Schumann, H. Prauser, R. Toalster, and E. Stackebrandt. 1993. Sporichthya polymorpha represents a novel line of descent within the order Actinomycetales. FEMS Microbiol. Lett. 109:263-268.

32. Rainey, F. A., and E. Stackebrandt. 1993. Phylogenetic evidence for the classification of Acidothermus cellulolyticus into the subphylum of the actinomycetes. FEMS Microbiol. Lett. 108:27-30.

33. Rainey, F. A., N. Weiss, H. Prauser, and E. Stackebrandt. 1994. Further evidence for the phylogenetic coherence of actinomycetes with Group Bpeptidoglycan and evidence for the phylogenetic intermixing of the genera 
Microbacterium and Aureobacterium as determined by $16 \mathrm{~S}$ rDNA analysis. FEMS Microbiol. Lett. 118:135-140.

34. Rainey, F. A., N. Weiss, and E. Stackebrandt. 1994. Coriobacterium and Atopobium are phylogenetic neighbors within the actinomycetes line of descent as derived by 16S rDNA analysis. Syst. Appl. Microbiol. 17:202-205.

35. Rainey, F. A., N. Weiss, and E. Stackebrandt. 1995. Phylogenetic analysis of the genera Cellulomonas, Promicromonospora, and Jonesia and proposal to exclude the genus Jonesia from the family Cellulomonadaceae. Int. J. Syst. Bacteriol. 45:649-652.

36. Relman, D. A., T. M. Schmidt, R. P. MacDermott, and S. Falkow. 1992. Identification of the uncultured bacillus of Whipple's disease. N. Engl. J. Med. 327:293-301

37. Ruimy, R., P. Riegel, P. Boiron, H. Monteil, and R. Christen. 1995. Phylogeny of the genus Corynebacterium deduced from analyses of small-subunit ribosomal DNA sequences. Int. J. Syst. Bacteriol. 45:740-746.

38. Saitou, N., and M. Nei. 1987. The neighbor-joining method: a new method for reconstructing phylogenetic trees. Mol, Biol. Evol, 4:406-425.

39. Srivastava, A. K., and D. Schlessinger. 1990. Mechanism and regulation of bacterial ribosomal RNA processing. Annu. Rev. Microbiol. 44:105-129.

40. Stackebrandt, E., C. Koch, O. Gvozdiak, and P. Schumann. 1995. Taxonomic dissection of the genus Micrococcus: Kocuria gen. nov., Nesterenkonia gen. nov., Kytococcus gen. nov., Dermacoccus gen. nov., and Micrococcus Cohn 1872 gen. emend. Int. J. Syst. Bacteriol. 45:682-692.
41. Stackebrandt, E., and H. Prauser. 1992. The family Cellulomonadaceae, p. 1323-1345. In A. Balows, H. G. Trüper, M. Dworkin, W. Harder, and K.-H. Schleifer (ed.), The prokaryotes, 2nd ed. Springer-Verlag, New York.

42. Strunk, O., and W. Ludwig. 1995. Unpublished data.

43. Takeuchi, M., and A. Yokota. 1994. Phylogenetic analysis of the genus $\mathrm{Mi}$ crobacterium based on 16S rRNA gene sequences. FEMS Microbiol. Lett. 124:11-16.

44. Thompson, D. E., J. T. Balsdon, J. Cai, and M. D. Collins. 1992. Studies on the ribosomal RNA operons of Listeria monocytogenes. FEMS Microbiol. Lett. 96:219-224.

45. von Herbay, A., H. J. Ditton, and M. Maiwald. 1996. Diagnostic application of a polymerase chain reaction assay for the Whipple's disease bacterium to intestinal biopsies. Gastroenterology 110:1735-1743.

46. Ward-Rainey, N., F. A. Rainey, and E. Stackebrandt. 1996. The phylogenetic structure of the genus Streptosporangium. Syst. Appl. Microbiol. 19:50-55.

47. Warwick, S., T. Bowen, H. McVeigh, and M. Embley. 1994. A phylogenetic analysis of the family Pseudonocardiaceae and the genera Actinokineospora and Saccharothrix with 16S rRNA sequences and a proposal to combine the genera Amycolata and Pseudonocardia in an emended genus Pseudonocardia. Int. J. Syst. Bacteriol. 44:293-299.

48. Wilson, K. H., R. Blitchington, R. Frothingham, and J. A. P. Wilson. 1991. Phylogeny of the Whipple's disease-associated bacterium. Lancet 338:474475 . 